$$
\begin{array}{ccccc}
\text { 松 岡 芳 子*, 富 } \text { 田 } & \text { 真佐子*, 吉 野 } & \text { 泉* } \\
\text { 細 } & \text { 田 } & \text { 裕 }^{* *} & &
\end{array}
$$

\title{
RELATIONSHIP BETWEEN AUTOIMMUNE DISEASES AND PNEUMOCONIOSIS
}

\author{
Yoshiko Matsuoka,* Masako Tomita,* Izumi Yoshino* \\ and Yutaka HosodA**
}

In recent years, with the aging of patients with pneumoconiosis, autoimmune diseases as a complication have been observed. One of the reasons for this may be that autoimmune diseases are prone to develop among the elderly.

On the other hand, it has been reported that dust itself, such as silica for example, has adjuvant effect. A review of the recent literature published in Japan and abroad was made to clarify the relationship between pneumoconiosis and autoimmune diseases and the following results were obtained.

1) Disorders which accompany pneumoconiosis: Scleroderma, rheumatoid arthritis, systemic lupus erythematosus (SLE), and disorders of the kidney and liver have been reported. In Japan, about 30 cases of pneumoconiosis accompanied with autoimmune diseases have been reported. In many of the reports, patients with pneumoconiosis and scleroderma have a past history of exposure to silica. In both case studies and case control studies, patients with rheumatoid arthritis and history of silica exposure are prone to develop pnemoconiosis.

2) Immunological studies of patients with pneumoconiosis: As for humoral immunity, elevation of polyclonal $\gamma$-globulin, especially IgG, has been often reported together with high positive rate of autoantibodies such as antinuclear antibodies. In cellular immunity, decreased delayed type skin reaction and decreased $\mathrm{CD} 4 / 8$ ratio have been reported. In human leukocyte antigen(HLA) typing the elevated frequency of DR4 has been reported. In the study of BAL increased production of superoxide anion $\mathrm{O}_{2}^{-}$by alveolar macrophages has been observed.

3) Experimental studies : Silica is well known for its toxicity to cells and also for its adjuvant effect. In the German Democratic Republic, patients with scleroderma and history of long term silica exposure are recognized as patients with occupational disease even though pneumoconiosis is not clearly demonstrated on X-ray film.

It is defficult from this review to nrake a definite conclusion regarding the relation between silicosis and autoimmune diseases. There is a need to repeat this review of the literature on autoimmune diseases and pneumoconiosis in the near future.

Key words : pneumoconiosis; autoimmune disease ; immunological response ; dust exposure

\section{I.はじめに}

近年, じん肺患者の高跉化に伴い，自己免疫疾㭧の合

* JR 東日本中央保健管理所

** 故射線疫学調查センター 平成 3 年 8 月 29 日受付

* Central Health Supervision Office, East Japan Railway Company

** Institute of Radiation Epidemiology

Received for publication, August 29, 1991
併が注目されてきている。しかし，じ肺も自己免疫疾 患もどちらも高路者に出現しやすいということもあり， 両者の因果関係は明らかにされていない，国内外の自己 免疫疾患を合併したじん肺症の症例報告，あるいは疫学 的な解析報告を検討してみると，合併する自己免疫疾患 の種類も，むた吸入粉しんの種類もさまざまである。さ らに，近年の免疫学の目覚ましい発展に伴い，兔疫学的 見地からのじん肺症の成立に関する臨床報告や実験報告 


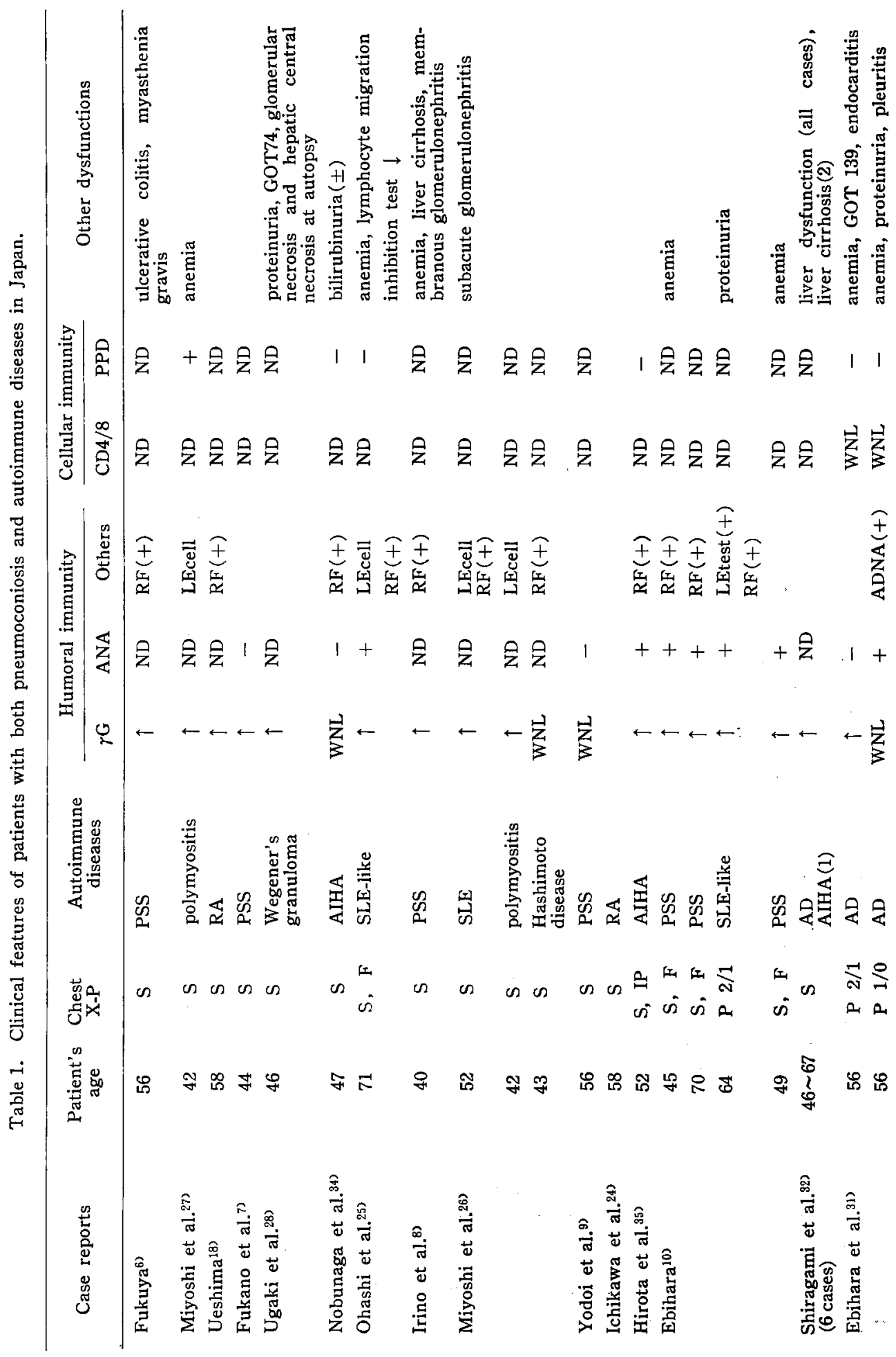




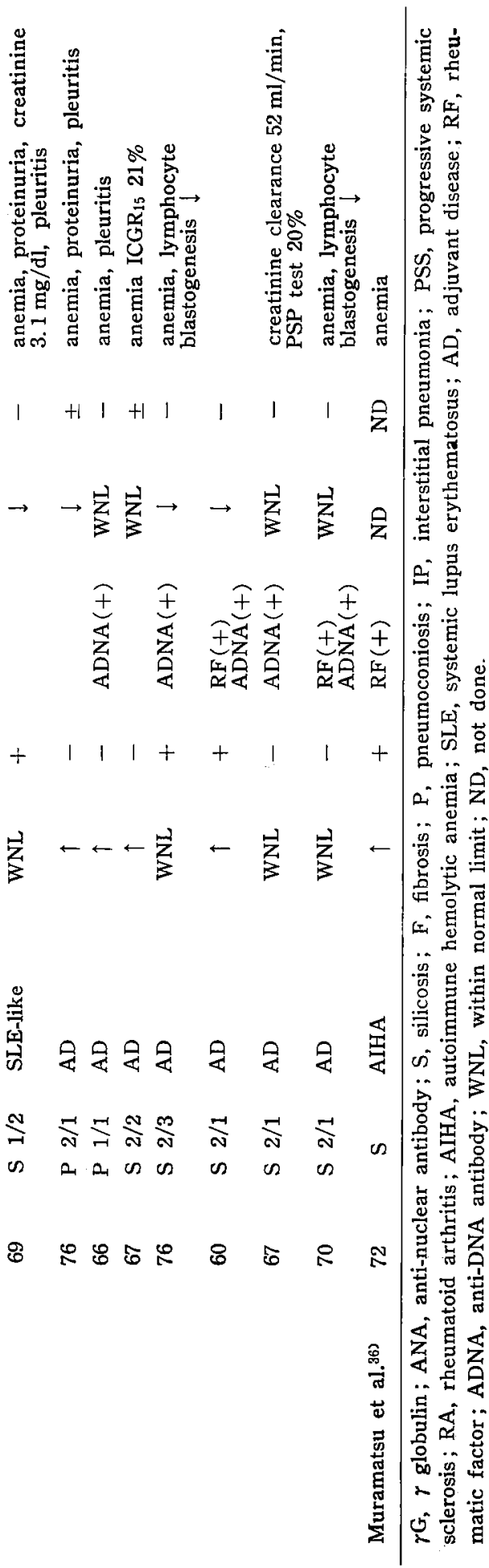

む相次ぎ，四入粉しんん含まれる物質がアシュパントと

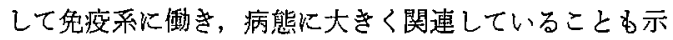
唆されてきている。

自己免疫疾患合併のしん肺症を引き起こした粉じんの 種類としては, ケイ酸粉しん, 硫化鉱粉しん, 石炭粉し んが主な粉しんとしてあげられる.中でも，けい肺㧍よ び炭鉱夫肺に関する報告が多い，石綿粉しんは鉱物学的 には線維状のケ酸塩であるが，非線維状のケイ酸やケ イ酸塩によるものとは免度応答が異なる面がみられ，自 己免疫疾患上りる，発癌性との関連を示咬する報告が多 い。今回のレビューではケイ酸粉しんおよび石炭粉じん について主にふれ，石綿に関しては別の機会にふれるこ ととする.

\section{II ・じん肺に合併した自己免疫疾患}

これまでに報告されている合併自己兔疫疾患を，疾患 別に述べる. 文献を入手しえた国内の報告例は Table 1 にまとめた。

自己免疫疾患といわ秃るものは，強皮症比し，全 身性エリテマトーデス（SLE）にしても，原因がはっきり していないため䠛床的沉診断基隼を決めて診断されてい， る.じん肺に自己免疫疾患を思わせる症状や免疫検查の 異常を伴っている場合，ヒトフシュバント病として記载 されている報告むある。フジュパントといらのは，それ 自体は免疫原性がないが，何らかの抗原と漉合して投与 するとその抗体産生能き細胞性免疫などの免疫反応を增 強する補助剂を指す。アジュバント病とは, 何らかの形 で体に入った物質がアジュバント効果を発揮して宿主に 有害な免疫反応引引き起こしてしまった場合を指してい る.実験的にはさまざまな動物でいるいるなアシュバン 卜を投与してアジュバント病を証明している。ヒトアシ ニバント病としてすでに報告されているのは, 乳房形成 術のためパラフィン注入を受けた症例1で，高熱，関節 痛, 高 $ク$ グロブリン血症などがみられ, なた, 同じく乳 房形成術のためシリコン注入を受けた女性例では関節痛 がみられ，強皮症も報告2きされている. シリカる実験的 にはアジュバント效果が認められて打り, 吸入粉じれ のシリカや，それ以外の粉じん成分がフジニバントとし て働き，人体の免疫応答を堌強させ，さらにはさまざま な形のアジュバント病を引き起こす可能性も十分考えら れるしいしながら，今回のまとめでは，フジュバント 病の内容が報告者により必ずしも一致していないので， Table 1 Kアジュパント病としてまとめてみたが，可能 な限り全身性自己兔疫疾患, あるいは䁍器別自己免疫疾 患として分類してみた。 


\section{1. 強皮症}

すでに 1914 年に Bramwell3) が石工に強皮症の発症 する頻度の高いことを報告している，その後 1957 年 Erasmus ${ }^{4)}$ が金鉱夫に発症している 17 例䘮報告し，こ のちち 6 例にけい肺のレントゲン所見がみられ，半数以 上の症例に強皮症特有の肺線維症の特徽がみられたとし ている：また，金鉱夫に和ける強皮症の頻度を，40/10 万人としている. 1967 年, Rodnan 553 は, 60 例の強 皮症の患者のうる，26 例 $(43 \%)$ にシリカ粉しん暴露歷 や，炭鉱夫の職業歷が認められたと報告している.これ ら 26 例は皮盛所見以外に, 関節, 内灆, 特に食道, 肺, 心蔵，腎蔵，胃腸にも病変が認められた。うち 19 例の 胸部レントゲン写真では，8例ニけい脑所見があり，カ テゴリー 1 が1例, カテゴリ -2 が5 例, カテゴリー3 が 2 例あった。しかし、カプラン症候群に特徵的な結節 は認められなかったまた，孷鉱夫での強皮症の頻度は 17/10 万人，非炭鉱夫の男性では 6/10 万人であった。

日本では 1967 年, 福屋6)が「けい肺症に合併した全 身性強皮症の一例」を報告して以来, 1970 年, 深野 が「けい肺症に合併した強皮症の一経験例」として 44 歳の元鉣夫の例を報告, 1972 年入野ら ${ }^{82}$ の 1 剖検例， 1973 年淀井ら 91 例報告が相 次ぎ，1982 年, 海老 原 ${ }^{103}$ が 3 例の強皮症合併けい肺例を報告している.

1985 年, 归東ドイツの Haustein ら ${ }^{112}$ は, 環境が起こし た全身珄強皮症様病的状態 (Environmentally induced systemic sclerosis-like disorders) と題する諭文の中 で, 86 例の強皮症患者につき検討を行っている，それに よると, 86 例の患者は職業性または非職業性に環境から のシリカ暴露歴があり， $ち$ ち 66 例 $(77 \%)$ にシリカの 職業性暴露歴があった. シリカの職業性暴露の有無にか かわらず，39 例 (45\%) がけい肺症に罹患しており，10 例 (12\%) 飞肺線維症の所見が認められた。けい肺症の 39 例中， 22 例はけい肺症が強皮症より先に発症し9例 では強皮症が先に，8例では両方同時に発症していた。

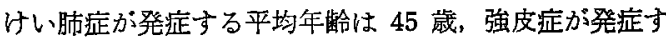
る平均年龄は 47.5 歳であった。これら 39 例は 38 例が 強皮症のアメリカ・リウマチ協会の基準を满たしており， 23 例は内缄障害（食道障害 14 例，抗核抗体陽珄 12 例， 腎障害 13 例) を伴っていた。 15 例は剖検されており， いずれも強皮正が主な死因と考えられた，また，シリカ の職業性暴露歴のある強皮症患者とそらでない患者との 比較子行って扣り，両者間に臨床症状，染色体の変化 （姉妹染色分体，異数体の増加， unstable $\mathrm{C}$ 増加）に 差はないとしている.この研究の結果,ドイッ民主和国 (旧東ドイッ)ではシリカに長期間暴露したことのある強
皮症の患者では，けい肺が末だ発症していなくても，強 皮症が粉じん暴露による職業病として諗識されるように なった。また, Sluis-Cremer ら は22 はシリカ,けい脑, 打よび進行性全身強皮症 (Silica, silicosis and progressive systemic sclerosis) という論文の中で, 南アフリ カの白人の鉿鉱夫にみられた 79 例の強皮症患者の検討 を行っている. 本論文では，強皮症患者の金鉱夫と，そ うでない金鉱夫でのけい肺症の頻度に差がなく，また， 強皮症とけい肺症との間に相関関係はなかったと否定的 である.しかしながら強皮症の症例のほらがョントロー ルに比ベシリカの蓄積量が有意に高く，乙かも暴露期間 よりも暴露量 (intensity) に関連したと報告し、シリカ が強皮症発症の誘因となりらると推察している.1987 年 Cowie ${ }^{13)}$ は元金鉱夫の黒人 10 例の強皮症を見出し, 33 〜 57 歳での発病頻度は 81.8/10万人/年であったと報告 しているまた，患者はすべてけい肺がなくても肺機能 低下を示し，結核の合併頻度も高かったとしている，ど の報告も、シリカ暴露が強皮症発症にまったく無関係で あると結論づけているものはなく、けい肺の発症と強皮 症の発症のいずれにもシリカが関与しうる可能性を示唆 するものが多い，けい肺と，強皮症の相関については， 否定的とする文献がみられているが，この二つの疾患の 発症に免疫応答の固体差が関与するならば必ずしも相関 していなくともよいのではないだららか。

1986 年の Barnadas ら 14 の 1 例は，けい肺と強皮症 のほかにインポテンスを合併し，1987 年の Agarwal ら ${ }^{15)}$ は，32 歳の石工がけい肺に強皮症を合併し，さらに 三叉神経領域扣よび末梢神経の知覚鈍麻や筋力低下を併 発した 1 例を報告している.この神経障害の病因につい ては不明であるが，今後神経障害の合併にも注意して観 察する必要がある。

\section{2. 関節リウマチ}

1953 年に Caplan ${ }^{16)}$ が関節リウマチを伴ったじん肺症 の炭鉱夫を報告し，以後カプラン症候群として記載され

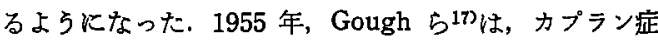
候群の炭鉱夫で，じん肺症による心不全あるいは結核て 死亡した 14 例を剖検し, 病理学的な検索を行っている. この時点ですでにリウマチ性じん肺結節は，普通のコ ラーゲン結節とは異なっており，周辺に活発な资症所見 を伴っていると報告し，カプラン症候群の胸部レントゲ ン写真の丸い陰影はリウマチによるものという病理学的 証拠はないとしている。その後もカプラン症候群の報 告18》数多くなされているが，その中では免疫学の進歩 に伴いさまざまな検索がなされている．免疫学的な考察 は後に別項目を設けて検討する。 
1973 年の Lippmann ら ${ }^{192}$ の報告では，軟炭を扱ら鉣 夫と無原炭を扱与鉱夫で抗核抗体の陽性率に差があるこ とから，粉じんの種類によってアジュバント効果が異な る可能性を示唆している，以後，石炭粉しんん種類につ いて, 1980 年 Hahon $5^{20)}, 1982$ 年 Boyd $5^{212}$ む比較 検討して㧍り，粉しんの種類によって引き起こされる自 己免度異常の種類が異なることを推察している，また， Boyd ら ${ }^{21)}$ は，䒜煙習摜の有無，年㱓の要素を考虑する と，抗核抗体については加龄や乫煙習慣の影響のほらが 大きく，じん肺の程度との相関はみられなかったとして いる. 石炭粉じん以外でも関節リウマチを合例するじん 肺症が報告されている. 1986 年 Sluis-Cremer ら アフリカの金鉱夫のケース・コントロール・スタディで 157 例の関節リウマチのある鉱夫のらち, definite 91 例, probable 66 例をリウマチのない鉱夫とけい肺の発症に 関して比較したところ，age-matchさせないとりウマチ 群はオッズ比 $2.84(p=0.0001)$ となり有意溌症しゃ すい. age-match させるとオッズ比は definite リウマ 千群 $3.79(p=0.0006)$, probable リウマチ群は有意差 なしとなり，両群のりウマチ因子陽性者はオッズ比 5.00 ( $p=0.0003)$ になった。 またリウマチ群のけい肺の進 展度は対照群より進んで括り，粉じん暴露総量や濃度の みでは説明がつかないとしている.

1983 年 Darke ら ${ }^{23)}$ はヒト白血球抗原 (HLA : human leukocyte antigen) の梌索索行い，して肺にかかりやす い,あるいはかかりにくいタイピングがいくつかあるこ とを見出している．このらち，DR4 飞関しては，すで に関節リウマチで多く見出される HLA のタイピングと して報告されているが，この諭文でもカプラン症候群に 多い傾向が認められたとしている，強皮症での検討と同 様に，多〈の症例報告から考兵ると，じ肺と関節りウ マチは少なから関連のあることが考えられるが，これ らの相関性を検討した論文の結果からは，二つの疾患の 関連性は強いものの，吸入粉しんに対する個体差，つま り別々の免度応答遗伝子の関与も少なからず大きいこと む示唆していると考えられる. 粉じの種類による免疫 応答の差については，反応する個体の条件が一致しなけ ればその差を明確にするのはむつかしく，症例報告から 結論つけるのは困難と考光られる。

関節リウマチに加えて，潰瘍性大腸炎も合併し，スト レプトマイシンにより筋無力症状を誘発されたけい肺症 の 1 例報告24)みられるが，粉じん暴露により強い感作 状態が引き起こされている可能性が示唆される.

3. 全身性エリテマトーデス (SLE)

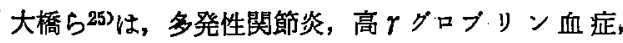

LE 細胞陽性その他から，SLE 類似の病態を合併したと 考克られたけい肺症の 1 例を報告しているし，三好ら ${ }^{262}$ む 52 嵅の例を報告している. しかし明らかな SLEを 合併したとする報告は多くはみあたらない。

\section{4. その他の全身性自己兔疫疾患}

三好ら 26,273 の多発性筋炎, および, 宇垣ら ${ }^{28)} の$ Wegener 肉芽尰症の 1 例の報告がある.

\section{5. 留障害}

1981 年 Bolton 5 292 が急性進行性シリコン腎症の 4 例を報告している. 9 年間粉じん作業に従事していた 39 歳の症例，および 1.6 年墓石の砂吹きをしていた 23 歳 の症例は, いずれも呼吸困難, 関節痛, 督機能低下を来 し死亡している. 1.7 年墓石の砂吹きをしていた 43 歳 の例では, 呼吸困難と蜸機能低下を示し, 肺生検で急性 けい肺 acute silicosis と診断され，副腎皮質ホルモン のパス療法にて軽快した. も51例は，鋳物工場で 3 年働いた 55 歳の例で, 拘束性肺機能障害と腎機能低下 を示し透析療法を行うよらになった．なた 1984 年の Miossec $5^{30}$ の報告では，58 歳の砂ふき業(職業歷 26 年) が, レーノー現象と体重減少, 関節痛にネフローセ （生娭では栄状区域性增殖性系球体腎炎 focal segmental proliferative glomerulonephritis) を合併した 1 例 を報告，抗核抗体，抗 dsDNA 抗体などの自己抗体が陽 性であったことから SLE との重複も考光られるとして いる.

わが国では，1985年，海老原ら尚が，粉じん作業者で アジュバント病と思われる11 例（けい肺 6例, その他 のじん肺 4 例，とえ肺所見のないるの 1 例）の中で 7 例 に何らかの堅障害を認めている，報告例から推察する限 り，粉じんが腎障害を引き起こす可能性のあることは明 らかであるが，じん肺患者に何らかの腎障害を考えさせ る所見たとえばたんぱく尿などがどの程度合併するの か，一般の集団と比較した文献はみあたらない。じん肺 に自己免疫疾患やアジェパント病として発症した患者の ほらが留障害が発見されやすいのか，こらいった自己抗 体などの関与とは別の機構で腎障害がもたらされるの か，現時点では不明であるとしかいえない。

\section{6. 肝障害}

ご肺の程度の強いものでは吸入された粉しんが肝内 にも沈着しているが，白神ら ${ }^{322}$ の報告では，けい肺症に 合併した 6 例の肝障害を発表している.肝腫大，肝の線 維化，ケイ酸の沈着などの肝障害以外に，ケグロブリン 上昇, 各種自己抗体陽性など, アジュバント病様の変化 る示している.

、肝組織中の粉じんの存在は，扣とらく貪食細胞を介乙 
て粉じんが体内に侵入している証明と考鼻てよいである ら.このことは，吸引された粉しんが沈着した粘膜上， あるいはその付近のみで異物として刺激源となる可能性 だけでなく，さらに体内に侵入して局所リンパ節等で免 疫反応に関連してくる可能性る示唆していると考克られ る.

\section{7. その他の臓器障客}

增田の報告33)によると，慢性甲状腺炎 90 例中 10 例に けい肺を発見，また，汁い肺 74 例について抗甲状腺抗 体陽性が 13 例 (17.5\%)（健常対照 1.7 3.4\%) と高 率に認められた。

自己免疫性溶血性貧血もけい肺症に合併した例が報告 されている

すでに述べてきたよらに，粉じんが体内でアジュバン 卜効果を示し，人によって免庭反応を必要以上に増強す ると考元られるが，引き起こされる自己兔疫疾患には個 人の免疫応答の差が大きく関わっていると考えられる。

\section{III. じん肺症の免疫異常について}

\section{1. 液性免疫}

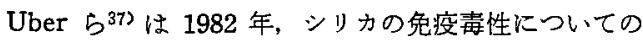
総説の中で、けい肺症では一般的に高 $r$ グロブリン血症 を起こす報告が多数あること，自己抗体の出現率の高い ことを述べている. 自己抗体の出現に関しては 1973 年 Kang ら ${ }^{38)}$ はしん肺之特発性肺線維症で抗核抗体の陽性 率を調べ，石綿肺では $34.4 \%$ ，けい肺では $25.8 \%$ ，特 発性肺線維症では $55.6 \%$ であったとしているが、コン トロール群として健康人特よび自己免疫疾患の比較対照 る置いていない. 1982 年の海老原の報告 ${ }^{103}$ の中ではしん 肺患者 71 例之慢性閉塞性肺疾患 COLD 患者 35 例を比 較し，ビん肺患者で血沈元進， RF 陽性，抗核抗体陽性， rグロプリン高値, IgG 高值であったと報告している. 特に石綿肺では RF 陽性，抗核抗体陽性が有意に高率で

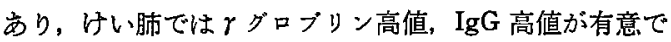
あったとしている．この 71 例のじん肺患者は, 検查時 点ではほとんどが自己免度疾患の合併は認められておら ず，粉しんによる液性免疫反応の增強が示㖫された。 の他自己免疫疾患の合併についての記載はないがじん 肺症での抗核抗体の陽性率を検討している報告は多い。 1983年 Rom 5 ${ }^{392}$ は炭鉣夫 238 人の血清中の抗核抗体 を調べ, $52 \%$ が 4 倍以上の陽珄を示し，そのはとえどが speckled pattern であったこと，抗体価の上昇につれじ ん肺の発生率も高くなり，抗核抗体の陽性率は年跲々粉 しん暴露歴の長さと相関していると報告している. 1984 年海老原 ${ }^{403}$ はじん肺療着患者 360 例を調べ, IgA，IgG,
抗核抗体陽珄は作業年数の増加, しん肺の進展に相関し ていると述へている。また，Youinou ら41)はけい肺 患者の anti-perinuclear factar (APF) と IgG クラスの リウマチ因子の陽性率を調べ，じん肺症でない自己兔疫 疾患やアルュール性肝障害での陽性率を比較している が，けい肺症での陽性率は APF はコントロールと差は なくリウマチ因子はコントロールょり高いものの，自己 免疫疾患群よりはずっと低い值である.この報告ではけ 、肺症は 19 例と少なく、けい肺の程度，合併症や年齢 の記载るなく，自己免疫疾患をはじめとする他疾患とけ い肺を，自己抗体との関連で検討した点は意義深いが， この結果をそのままけい肺の特徴と考えるのは危険であ ろう. 1989 年の Idel の報告42》では，けい肺症患者の血 清 400 検体を調べ, 粉じん暴露歴のないコントロールと 比へ，IgG，A， M 抗体の上昇，補体成分 $\left(C_{3}\right)$ ，抗核抗 体陽性率の上昇や免疫複合体の增加が認められ，また， ライソゾーム, アンギオテンシン転換酔素, ファイブロ ネクチンなどのマクロファージ活性化を推察させる血清 中のいくつかの指標の上昇がみられたとしている. しか し，これらは血清中の測定であり，マクロファージ活性 化の亩接の証明とはいえず，また，局所の反応をそのま ま反映しているわけではない。

自己免疫疾患合併のしん肺症の液性免疫としては，ポ リクローナルなケグロブリンの増加, 特に IgG の増加 が多くみられ，自己抗体では抗核抗体，抗 $\mathrm{Sm}$ 抗体，リ ウマチ因子，クッパー細胞 Kupffer cell に対する自己抗 体レチクリン抗体, 抗甲状腺抗体，ヶラトヒアリン顆粒 に対する自己抗体 APF，抗 DNA 抗体などが陽性に出 ている報告がある. ほとえどが缄器非特巽的な自己抗体 であるるのが陽性である報告が多い、抗肺抗体が認めら れるけい肺症の報告25) あるが，この報告例では抗核抗 体や抗 DNA 抗体などの自己抗体も陽性であり，抗肺抗 体のみが特異的に病態に深く関わっているとは考克られ ない.

\section{2. 細胞性免疫}

しん肺症の細胞性免疫は低下していると考えられる が, Uber ら ${ }^{37)}$ の総説でもツ反の减弱, 皮膚移植片拒絶 反応の遅延, 易感染性, 特にウイルス, 真菌, 抗酸菌に 対する抵抗力の減弱をあげている，海老原ら401は，しん 肺療養者のリンパ球サブセットでT細胞比率の隇少, OKT4/8 比の低下, 末梢単核球の PHA (phytohemagglutinin) に対する奻若化反応の低下などが，じ肺の 進展度に比例している，と報告している. Youinou ら は, シリカ暴露歷のあるものは, シリコーシスの患者も 患者でないすのも OKT8 細胞が age, sex-matched 
control に比べ低下していると報告している. そして抗

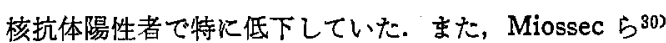
はサプレッサーT細胞が属すると考劣られる $T_{G}$ 細胞の 比率も低下乙，血中の免疫複合体量と逆相関していたと 報告している，自己免疫疾患合併例では，1976 年 Dau-

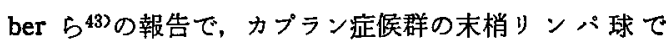
は, EAC口ゼット陽性細胞の比率の低下と，自己血清 を培責液に添加して Concanavalin A で刺激したときの 反応の低下から， $\mathrm{T}$ 細胞， $\mathrm{B}$ 細胞いずれもコントロール に比べ,变化があったとしている．また，海老原ら 報告した 10 例のフシュパント病の患者では全例ッ反が 陰性ないし䞨陽性であり，10 例中 4 例に OKT4/8 比の 低下を認めている，T細胞マーカーの検索に関しては報 告によって相反する結論が出されているのが現状である が、リンパ球サブセットの変化の意味を決定するには， 検索した症例数があまりに少なく，現状では困難である 5. 最近では細胞マーカーに対する多くのモノクロナル 抗体が開発され，サブセットや機能に関してるさらに細 分化して種々の免疫疾患の解明に応用されている.でん 肺関連の疾患でも，細胞性免疫に関する報告はむしろこ れから積極的になされ，意味付けされるであるう。

\section{3. ヒ上白血球抗原 (HLA)}

1983 年 Darke らの報告23) では, カプラン症候群の HLA を調べた結果，カプラン症候群を伴わない炭鉱夫 や非炭鉱夫の健常コントロールに比べ，しん肺患者群て B27 の頻度が有意に低いが，じ肺患者群で有意に高い ものはなく，B5，8，27，w45，DR4，2 が高い傾向をみ

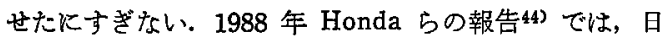
本人のけい肺症患者と関節リウマチ患者の HLA を比㜞 し，Bw54，DR4，DRw53の頻度がいずれの疾患群でる 有意に高く，Bw52，DR2 を持つ頻度は低かった，関節 リウマチに指ける DR4 の頻度の高いことは多くの文献 にすでに報告されており，けい肺患者に DR4 の頻度が 高いことは，カプラン症候群との関連を考えるとき與味 樑い.

\section{4. 肺病变の免疫学的变化}

病理学的にはじん肺症の肺病变に関する報告は数多く あり，しん肺結節に集まる炎症性細胞，免疫グロブリン やヒフリンなどの沈着, 線維化など詳細は専門書に譲る とするが，今回レビューした文献をみる限りは従来の染 色法に加えてモノクロナル抗体などを使った新しい免疫 学的フプローチを試みた報告はみあたらない，最近肺病 変の解明に大变有力な手段となった気管支肺胞洗浄液 (BALF) 中の細胞成分の分析に上る病变の解析の試みは じん肺症ですいくつか報告がみられる.より正確な病態
把握のためには Rennard ら45の提唱するよ5に気管支 と肺胞の内容物をできる限りわけて採るなど BALF の 採取方法注意を払うことも必要であるら.1987年 Rom ら 4 (6) は石綿肺，炭鉱夫肺，けい肺患者で，非製煙者の BALFを調へ，肺胞マクロファージの生体内での活性酸 素 $\mathrm{O}_{2}{ }^{-}$, 過酸化水素 $\mathrm{H}_{2} \mathrm{O}_{2}$ やファイブロネクチンの産 生が亢進して掠り線維芽細胞堌殖因子む産生増強してい たと報告している：これらの症例に自己免疫疾患が合併 したかは記载がない. 1990 年, Wallaert ら47は非梨煙 炭鉱夫の単純しん肺 simple pneumoconiosis (SP) と, 進行性塊状線維性じ肺 progressive massive fibrosis (PMF) の患者で, 肺胞マクロファージの生体内での $\mathrm{O}_{2}-$ の産生が $\mathrm{SP}$ でコントロールの3〜4倍, PMF で はさらに高值であることを報告し，これがマクロファー $\forall の \mathrm{O}_{2}$ - 分解酵素久損によるのではないことを証明して いる.これらの報告から, 肺胞マクロファージは肺胞内 ですでに活性化されて $\mathrm{O}_{2}$ - を産生し，この $\mathrm{O}_{2}-$ が肺の 組織障害と関連していると考えることができる。

\section{5. 実験による粉じんの免疫系への影響の検討}

じ肺症の病態を明らかにして，疾病の予防，進行の 阻止，治療の方法を確立するために，in vitro，in vivo の実験は必要欠くべからざるものである.実際にじん肺 症と自己免疫疾患を合併して発症する実験モデルがみつ かれば，非常に有力な研究手段となるであるう。しかし ながら手元の文献ではこのよらな実験はみあたらない。 加龄とともに自己免疫疾患を発症する純系マウスがみつ かっているが，このような実験モデルに粉じんの吸入を 試みる可能性る考えられる.

粉じんの種類別による検討では，ほとんどの奏験で使 われているのはシリカである. シリカむ粒子サイズ等で いくつかの種類があるし, シリカ以外の粉じんはコント ロールとして使われているすのが多い，以下，実験論文 の紹介では, quartz と記されているものもシリカと書 かれているものも，単にシリカと記載する.

動物実験では, 1959 年 Powell ら ${ }^{482}$ はウサギの胸腔内 にシリカを注入しシリコン肺を実験的に作らせたが，こ の際，ウサギにウマ血清を投与して過敏性を高めておく と, シリカへの反応性も高まり, シリカへの個体の感受 性に差がありらることを示唆した. しかし，ステロイド はシリカへの反応性を抑制した，と報告した. 1962 年 Pernis ら ${ }^{49}$ はシリカ(トリジマイト) の抗体産生に及 ぼすフジニ゙ンント効果をウサギのin vivo 実験で証明し ている. 1968 年, Szymczykiewicz ${ }^{50)}$ の論文によるとウ サギまたはモルモットに実騟的に肺線維症を起こさせた が, その際, 結晶性のクリンタイルやケイ酸で処理した 
場合はとグロブリンの上真がみられたが，無晶性のクリ ソタイルや石炭ではみられなかったことを報告し，粉じ んの種類や結晶形態と病原性に関連があるのではないか と推察している。 また，別の論文で、 、ゥスにシリカを 静注して特異抗体産生に対するそのアジュパント効果を 調べているものもある51)。一方シリカを貪食するのはマ クロファージであるので, マクロファージに対するシリ カのアジニバント効果のみでなくその毒性を調べ，その

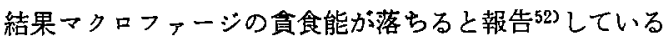
ものもある.この実験では，静注したシリカの濃度が高 い可能性があるが，別の報告で, シリカを吸入暴露させ たマウスの実験で，末梢血，縦隔リンパ節，胸腺および 脾臓のB 細胞機能や，細胞性免疫いずれも著明に低下 し, 血清中にB 細胞機能抑制因子のあることが示唆さ れ，かつまたこの抑制は暴露を中止しても 3 か月続いて いた，と報告53)しているものもある. Lugano ら54はも ルテットにシリカを気管内注入し，その肺胞マクロファ ージから産生される線維芽細胞增殖因子を測定している が，暴露 2 日のものでは増殖因子の産生は抑制され，42 〜180日暴露したものでは産生增強していた，と報告し ている. Brody ら ${ }^{55}$ はラットにシリカを吸入暴露し, 吸 入後の肺組織のシリカの沈着の様子や遊出細胞の種類を 観察している.それによるとシリカはタイプI 細胞，間 質細胞，結合組織，マクロファージに吸着している. 35 〜65\% のマクロファージが取り込んでいるが，その 14 \%は壊死している，遊出細胞はマクロファージと好中球 が多い. Bignon $5^{56)}$ の報告では粉じんを気管内注入し たラットの肺胞洗浄液中のマクロファージの粉じ粒子 貪食による細胞破壊を観察しているが，その程度はシリ カ,クロシドライト，クリソタイルの順に強かったと報 告している.

ヒトの細胞を使った in vitro の実験では, 1984 年, Schmidt ら ${ }^{57}$ はヒト末梢血単核球を使った in vitro の 培柱実験で，シリカを加えると線維芽細胞普殖因子の産 生がみられたが，ダイアモンドダストではこの効果はみ られず，この增殖因子はインターロイキン1であるらと 報告している. 1989 年 Klein ら ${ }^{58)}$ はヒト末梢血単球に 対寸るシリカの毒性を in vitroでみているが, 個人差, 日差が強かったと報告している．これは，検者の技術的 な問題すあるかもしれないが，しん肺発症の個人差の反 映かむしれない. Ghio $5^{592}$ は，シリカによる肺病変が オキシダントによるものとの仮説を発表し，その産生さ れる病態の解析を行っている.

多くの文献では粉じんによる自己免疫疾患発症のメカ ニズムを主に個人の免疫能の差異に基づくすのと推察し
Table 2. List of particulate matters which can give rise to pneumocociosis. ${ }^{64}$ )

Asbestos
Alumina:or alminum oxide
Aluminum
Micas
Clays
Diatomaceous earth (amorphous silica)
Mineral fiber
Graphite (natural)
Cristobalite
Iron oxide (welding fume)
Quartz
Talc
Coal dust
Carbon black
Steatite (talc)
Tridymite
Tripori
Perlite
Fly ash
Portland cement
Fused quartz
Sulphide minerals
Roseki, pyrophyllite (agalomatolite)

ているが，粉しんの種類による差異について言及してい るむのもある 19 21,50,56). Table 2 Kはしん肺法施行規則 別表第】に記載されたしん肺起因物質をあげた. 英訳に 伴って一部改変されている。じ肺起因物質とされてい る粉じんが必ずしも単一の成分から成っているわけでは ない，構成成分の分析とその一つひとつの成分に対する 実験的裏付けが必要かと思われるが，今回集めた文献で はほとんどシリカの書性に関するもののみであった.

\section{IV. まとめ}

いわゆる自己兔疫疾患は，SLEにしても関節リウマチ にしても診断基準は定められているが，原因について単 一の病因が決定しているものはない，䧹患しやすい㑯向 については遺伀性があると考兵られているが，誘因につ いてはっきりしたものはない，言い換えると，一部の免 疫応答遗伝子の異常が存在し， T細胞，B細胞やマクロ ファージなどに発現すると考えられるが，その異常が疾 忠として発現するためには何らかの環境因子，たとえ ば,ウイルス感染やホルモン異常などが関与すると考え 
られている，その一つの可能性として粉じん吸入があげ られる. 一方しん肺も粉しん吸入と疾患の因果関係がか なり明らかになってはいるるのの，しん肺の発病には個 人差も西るし，粉じんの中のじん肺起因成分も必ずしも 明確にされているわけではない、じ肺も自己免疫疾患 も発病の原因や病態に依然不明確なところが数多く残さ れており，その二つの疾患群の因果関㐿を明らかにする のは非常に困難な仕事である.これまでに述べてきた多 くの報告の事実から推論し，少しでも可能性の高い関連 性を考えてみたい。

じん肺と自己免疫疾患の関係を想定してみると，Fig.

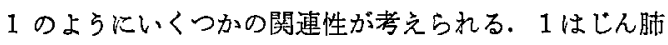
と自己免疫疾患の間には何の関連るなく，合併した症例 は単に偶発的なるのであるといら仮定である，2は，円 の重なる部分が合併例群であり，粉しん暴露下で一部の 自己免疫疾患の素因を持つ人が合併症例となるといら仮 定である. 3 はじん肺そのものが粉じんにより誘発され た一種の自己免疫疾患であるという仮定である.つま り，自己免疫疾患のみでもいろいるな疾费があり，さら にそれらがオーバーラップしている症例も多数みられる ので，じん肺と自己免疫疾患の合併例もオーバーラップ したものと考える仮定である。

1 の仮定は Sluis-Cremer 5 ${ }^{122}$ の述べている考え方で あるがそそれでもな和シリカと強皮症の関連を否定して いるわげではない：なた観察を行ったときにレントゲン 的にけい肺のなかった例について，その後の経過や呼吸 機能については言及していない。

一方, Erasmus', Rodnan 55), Cowie ${ }^{(3)}$ は一般と の発生頻度の比較で粉しん暴露者に強皮症が多いことを 述べ，この仮説には否定的である. Sluis-Cremer るリ ウマチに関する報告22)では definite リウマチ群にしん肺 が発症しやすいと述べ，両疾患群に関連性のあることを 推測している.

ほとんどの疫学的な檢討は 2 の仮定を考えていると思 われる. Darke ら"3)の報告にみられる HLA の検索はこ れを直接証明しようとしたものと思われる，今のとこ ろ，HLA に関する報告はそれほど多くはないが，タイ ピング法もさらに発展してきているので, 同一のタイプ での粉しん暴露群, 非暴露群の比效など, 今後も検討を 重わることが望まれる.

3 の仮定はじん肺症の免疫学的病態が明らかにされな くては肯定も否定もできないが, 粉しん暴露があっても しん肺症を発症しない群をる詳細に検討する必要がある 5.この仮定は，古くから論しられており，1958 年に Vigliani and Pernis ${ }^{60)}$ が総説の中でまとめている.

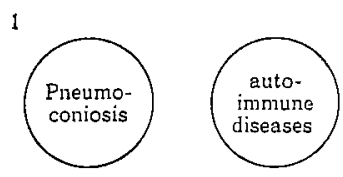

2

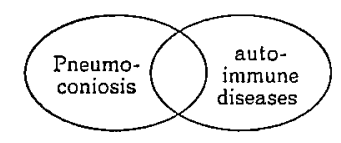

3

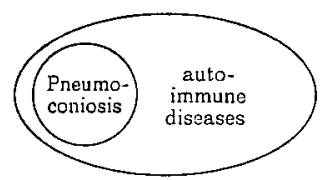

Fig.1. Correlations between pneumoconiosis and autoimmune diseases.

いずれにしても、疫学的検討はコントロールの条件を 一定にしなければ比較が難しく、コントロールの取り方 によって odds ratio も変わってくる ${ }^{61)}$. しん肺症と自 己免疫疾患の関連性を否定する諭文む出されているか， 否定されたものはどらいら条件での解析か，詳細に吟味 しなくてはならない62).すなわち，しん肺と自己免疫疾 患の合併を，頻度的に両者の関連性を否定していても， 粉しんそのものと自己免疫疾患の発症の関連を否定して いるわけではない場合もあるからである.

患者の諸検査については, 非特異的自己抗体の出現の 報告が多く、シリカのアジニバント効果についての害験 結果と一致していると思われる. シリカが一度吸入沈着 すると排泄されがたく，吸入を止めてもその刺激が持繹 する.したがって，たとえ局所であってもそのために免 疫系が刺激を受け，炎症性の細胞なと゚により破塆された 自己組織を抗原として免疫反応が起こり, さらにシリカ がアジュバント効果を示し，その結果として自己抗体の 出現をみることも考光られる。

肺胞マクロファージのシリカによる刺激の状態を検索 することは大きな鋌を握っていると思われるが，肺局所 の免疫検査は特に臨床例の報告が之しく，しん肺のみの 場合と，自己免疫疾患の場合と，合併例とを条件を揃え て比較した報告はないので結論を得ることができない。

すでにあげた諸文献の汪かにも優れたレビューが出さ れている63.．いずれの論文でも，粉しん暴露下での自己 免疫疾患の発症を，じ肺との合併として安易に考皇る だけでなく，「粉じん暴露と自己免疫疾患」の相互関係 
をいるいるな観点から研究していく必要性を示咬してい る. 今後は粉しん暴露のない自己免疫疾患㭧者と，粉じ 几暴露のある自己免疫疾患㭧者, 粉しん暴露の及で自己 免疫疾患を発症していない群，これらのリスクの何むな いコントロール群を, 性, 年路を合致させて比較検討す ることが望むしい。特に, 肺局所の病变を, 病理組織学 的に比較するだけでなく，BALF 中の細胞を使用した免 疫能の測定などの新しい手法を用い，in vivo の病変を in vitro で推定，あるい確認するようなフプローチが 必要であるし，動物実験でるこれらの病変を免疫学的に

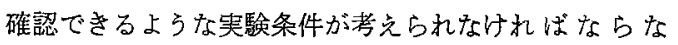
い.ことに粉じん作業従事者の瞕業病としての自己免疼 疾患の可能性, といら観点もふくめ, 疫学的飞も臨床的 にも，さら娭討する必要があうう。

稿を终えるにあだって，粉しんの英訳をこ指導くださいまし た秋田大学鉱山学教室林久人教授に深諎いたします。

\section{文献}

1）三好和夫，宮岡輝夫，小林泰雄，ほか. 人体に括ける adjuvant 加遷延感作を思わせる高 $\gamma$ グロブリン血症一乳房 形成術の後にみられた障害. 医事新報 $1964 ； 2122: 9-14$.

2) Baldwin CM, Kaplan EN. Silicone-induced human adjuvant disease? Ann Plast Surg 1983; $10: 270-273$

3) Bramwell B. Diffuse sclerodermia; its frequency; its occurrence in Stonemasons, its treatment by fibrolysin-elevations of temperature due to fibrolysin injections. Edinb Med J $1914 ; 12: 387-401$.

4) Erasmus LD. Scleroderma in gold-miners on the Witwatersrand with particular reference to pulmonary manifestations. South Afr J Lab Clin Med 1957 ; $3: 209-231$.

5) Rodnan GP, Benedek TG, Medsgex TA, Cammarata $R J$. The association of progressive systemic sclerosis (scleroderma) with coal miners' pneumoconiosis and other forms of silicosis. Ann Intern Med $1967 ; 66: 323-334$.

6) 福屋正史. けい肺症に合併した全身性强皮泟の一例. 鉱 山医誌 $1967 ; 7: 22$.

7) 深野浩一, 梶原長雍, 藤居 光, 橋田 隆, 平岡 到. 肺症に合併した強皮症の一経験例. 日内会誌 $1970 ; 59$ : 298.

8）入野敏夫，岩波黄葵，丸山定之，忠田守喜. 沉発性珘皮 症を合併した珪肺症の1剖搔例. 日本臨床 $1972 ； 30$ : 1030-1042.

9) 淀井涪司, 内田温士, 藤田 宗, 恒松徳五郎, 深瀬政市, 高島昭佳. 珪肺症に合併した沉発性強皮症の 1 症例. 日内 会誌 $1973 ; 62: 427-428$.

10）海老原勇.じん肺症に欢られる自己免疫疾患に関する臨 床的研究. フレルギー 1982；31: 189.

11) Haustein UF, Ziegler V. Environmentally induced systemic sclerosis-like disorders. Int J Dermatol $1985 ; 24: 147-151$.

12) Sluis-Cremer GK, Hessel PA, Nizdo EH, Chur- chill AR, Zeiss EA. Silica, silicosis and progressive systemic sclerosis. Br J Ind Med $1985 ; 42: 838-843$.

13) Cowie RI. Silica-dust-exposed mine workers with sclerodema (systemic sclerosis). Chest 1987; 92: 260-262.

14) Barnadas MA, Tuneu A, Rajmil HO, Abudo O, de Morgas JM. Impotence in silicosis associated scleroderma. J Am Acad Dermatol Corresp 1986; 15 (6) : 1294-1296.

15) Agarwal R, Vasan RS, Singh RR, et al. Trigeminal and peripheral neuropathy in a patient with systemic sclerosis and silicosis. Clin Exp Rheum $1987 ; 5: 375-376$.

16) Caplan A. Certain unusual radiological appearances in the chest of coal miners suffering from sheumatoid arthritis. Thorax $1953 ; 8: 29-37$.

17) Gough J, Rivers D, Seal RME. Pathological studies of modified pneumoconiosis in coal miners with rheumatoid arthritis (Caplan's syndrome). Thorax $1955 ; 10: 9-18$.

18）上島宏一. 人アシュハンント病としての珪肺症. 四国医誌 $1968 ; 24: 513-528$.

19) Lippmann M, Leckert HL, Hahon N, Morgan WKC. Circulating antinuculear and rheumatoid factors in coal miners. Ann Intern Med 1973;79: 807-811.

20) Hahon N, Morgan WKC, Petersen M. Serum immunoglobulin levels in cal workers' pneumoconiosis. Ann Occup Hyg $1980: 23: 165-174$.

21) Boyd JE, Robertson MD, Davis JMG. Autoantibodies in coal miners: their relationship to the development of progressive massive fibrosis. Am $\mathrm{J}$ Ind Med $1982 ; 3: 201-208$.

22) Sluis-Cremer GK, Hessel PA, Hnizdo E, Churchill AR. Relationship between silicosis and rheumatoid arthritis. Thorax $1986 ; 41: 596-601$.

23) Darke C, Wagner MMF, Nuki G, Dyer PA. HLA$A, B$, and $D R$ antigens and properdin factors $B$ allotypes in Caplan's syndrome. Br J Dis Chest $1983 ; 77: 235-242$.

24）市川幸延, 的場邦和, 中田安成, 有森 茂. 珪肺症湓慢 性関節リウマチ，潰痬性大踼炎を合併し，ストレブトマイ シンにより觔無力症状を誘発した1 例. 最新医学 1975 ； 30 (3) : 465-472.

25）大橋 晃, 入宇田能順, 仲 紘嗣. 高グロブリン血症を 伴い adjuvant 病様病像を呈した珪盿症の一症例. 日内 会誌 $1973 ; 62: 620-625$.

26）三好和夫, 白神 窝, 吉田和代. 人アジュバント病. 蹦 床兔疫 $1973 ; 5: 785-794$.

27）三好和夫, 上島宏一,八木田正聖, 法. 人体 Adjuvant 病之しての珪肺症，多発性筫炎症状を呈した特殊例. アレ ルギー $1967 ; 16: 169$.

28）宇垣公最, 渡边晃次, 岡田 茂. 珠肺火合併した Wegener 肉芽㢆定の一例. 日多害医誌 $1973 ; 19: 241-247$.

29) Bolton WK, Stuart PM, Stugrill BC. Rapidly progressive silicon nephropathy. Am J Med 1981; $71: 823-828$.

30) Miossec P, Youinou P, Cledes J, et al. Lowered Fc IgG receptor bearing $T$ lymphocytes correlate with non-organ specific autoantibodies in silicosis. Int Arch Allergy Appl Immunol $1984 ; 73: 212-215$.

31）海老原勇, 川見正機. 粉しん作業者にみられるマシュバ 
ント病と思われる症例に関する臨床的研究. フレルギ$1985 ; 34: 1028-1039$.

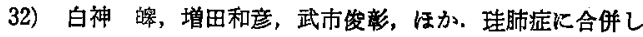
た肝障害一球酸アジェパントとしての肝病変.フレルギー $1983 ; 32: 760$.

33）增田和彦.人アシュペント病としての珪肺症に見られる 僈性甲状腺炎，四国医誌 $1981 ； 37: 119-129$.

34）延永 正，橋永邦彦，末宗敬康. 珠肺症患者に見られた 溶血性爷血. 臨床免度 $1972 ; 4: 935-939$.

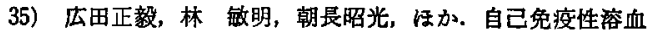
性筫血と間質性盹炎の合併をとるなった人フジニバント病 の一例. 日胸 $1979 ; 38(1): 58-62$.

36) 村松公美子, 山本 保, 長谷川明, 以か. 自己免废性督 血を合併した珪肺症の一例. 日胸 1989；48(1)：45-50。

37) Uber CL, McReynolds RA. Immunotoxicology of silica. Crit Rev Toxicol $1982 ; 10: 303-319$.

38) Kang $K Y$, Yagura $T$, Sera $Y$, Yokoyama $K$, Yamamura $Y$. Antinuclear factor in pneumoconioses and idiopathic pulmonary fibrosis. Med $\mathrm{J}$ Osaka Univ $1973 ; 23(4)$ : 249-256.

39) Rom WN, Turner WG, Kanner RE, et al. Antinuclear antibodies in Utah coal miners. Chest $1983 ; 83: 515-519$.

40）海老原勇, 川見正機. 粉しん作業者の液性, 細胞性免疫 能に関する疫学的研究. フレルギー $1984 ; 33: 808$.

41) Youinou P, Ferec C, Cledes J, et al. Immunological effect of silica dust analyzed by monoclonal antibodies. J Clin Lab Immunol $1985 ; 16$ : 207-210.

42) Idel $\mathrm{H}$. Immunological changes in silicosis : cause or consequence? Silicosis Report North-Rhine Westphalia 1989 ; Vol 17 : 343-350.

43) Dauber JH, Finn DR, Daniele RP. Immunological abnormalities in anthrosilicosis. Am Rev Respir Dis 1976 ; 113 : 94 .

44) Honda K, Hirayama K, Kikuchi I, Nagato H, Tamai H, Sasazuki T. HLA and silicosis in Japan. N Engl J Med 1988; 15: 1610.

45) Rennard SI, Ghafouri $M$, Thompson $A B$, et al. Fractional Processing of sequential bronchoalveolar lavage to separate bronchial and alveolar samples. Am Rev Respir Dis $1990 ; 141$ : 208-217.

46) Rom WN, Bitterman PB, Rennard SI, Cantin A, Crystal RG. Characterization of the lower respiratory tract inflammation of nonsmoking individuals with interstitial lung disease associated with chronic inhalation of inorganic dusts. Am Rev Respir Dis 1987; 136 : 1429-1434.

47) Wallaert B, Lassalle P, Fortin F, et al. Superoxide anion generation by alveolar inflammatory cells in simple pneumoconiosis and in progressive massive fibrosis of nonsmoking coal workers. Am Rev Respir Dis 1990; 141 : 129-133.

48) Powell DEB, Gough J. The effect on experimental silicosis of hypersensitivity induced by horse serum. Br J Exp Pathol $1959 ; 40: 40-43$.

49) Pernis B, Paronetto F. Adjuvant effect on silica (tridymite) on antibody production. Proc Soc Exp
Biol Med $1962 ; 110: 390-392$.

50) Szymczykiewicz K. Niektore Zagadnienia Etiologii I. Patogenezy Azbestowej. Med Pr 1968; XIX (2) 152-173.

51) Spitznagel JK, Allison AC. Mode of action of adjuvants; retinol and other lysosome-labilizing agents as adjuvants. J Immunol $1970 ; 104: 119-127$.

52) Levy MH, Wheelock EF. Effects of intravenous silica on immune and non-immune functions of the murine host. J Immunol $1975 ; 115: 41-48$.

53) Miller SD, Zarkower A. Silica-induced altera tions of murine lymphocyte immunocompetence and suppression of B lymphocyte immunocom petence : a possible mechanism. J Reticuloendothel Soc $1976 ; 19: 47-61$.

54) Lugano EM, Dauber JH, Elias JA, Bashey RI, Jimenez SA, Daniele RP. The regulation of lung fibroblast proliferation by alveolar macrophages in experimental silicosis. Am Rev Respir Dis 1984; $129: 767-771$.

55) Brody AR, Roe MW, Evans JH, Davis GS. Deposition and translocation of inhaled silica. In : Gee JBL, Morgan WK, Brooks SM, eds. Occupational Lung Disease. New York: Raven Press, 1984 : 168169 .

56) Bignon J, Maho SL, Lambre C, Jaurand MC, Masse R. Cellular and biochemical acute alveolar responses to asbestos and quartz dusts in rats. In: Gee JBL, Morgan WK, Brooks SM, eds. Occupational Lung Disease. New York : Raven Press, 1984 176-177.

57) Schmidt JA, Oliver CN, Lepe-Zuniga JL, Green I, Gery I: Silica-stimulated monocytes release fibroblast proliferation factors identical to interleukin $1:$ a potential role for interleukin 1 in the pathogenesis of silicosis. J Clin Invest $1984 ; 73$ : $1462-1472$.

58) Klein B, Posteher S, Bruch J. Results of studies on dust suppression and silicosis prevention in hard coal mining. Silicosis Report North-Rhine Westphalia 1989 ; Vol $17: 237-245$.

59) Ghio AJ, Kennedy TP, Schapira RM, Crumbliss AL, Hoidal JR. Hypothesis: is lung disease after silicate inhalation caused by oxidant generation? Lancet $1990 ; 336: 967-969$.

60) Vigliani EC, Pernis B. Immunological factors in the pathogenesis of the hyaline tissue of silicosis. Br J Ind Med 1958; 15:8-14.

61) Hessel PA, Sluis-Cremer GK. Control group selection in the studies involving compensation for occupational disease. Int Arch Occup Environ Health, 1987 ; $59: 97-105$.

62) Members of Silicosis and Silicate Disease Com. mittee, National Institute of Occupational Safety and Health. Diseases associated with exposure to silica and nonfibrous silicate minerals. Arch Pathol Lab Med $1988 ; 112: 673-720$.

63）海老原勇. 粉しんと健康障害一継続的な免疫疾患として の把握一. 東京：労働科学研究所出版部, $1986: 1-162$.

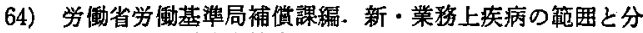
類. 東京：労働法令協会，1988：44。

著者への通信先 : 松岡芳子, =151 東京都渋谷区代々木 2-1 JR 東日本中央保健管理所 Reprint. requests to Central Health Supervision Office, East Japan Railway Company, Yoyogi, Shibuya-ki, Tokyo, 151 Japan (Y. Matsuoka) 